\title{
INTEGRATED CHARACTER EDUCATION MODEL SEBAGAI ALTERNATIF SOLUSI MENGATASI DEGRADASI MORAL PELAJAR INDONESIA
}

\section{Prasetiawati $^{8}$}

\begin{abstract}
In the middle of globalization era and today's modernization, the nation character and moral is one of the main many problems are facing by developing countries included Indonesia. Base on this, today's social fact showed thadt the moral degradation has happened among Indonesian students. It became irony or our country continuation in the future and made writer interested in constructing all the integrated character education models and their relevance toward the effort that overcome moral degradation of Indonesian students. At the end of this writing is concluded that Integrated Character Education Models become important and relevant to be determined to overcome student moral degradation, it also the effort in creating strong student character to face life cgallenge in the future.
\end{abstract}

Keywords: Integrated Character Education Model, Moral Degradation, Students

${ }^{8}$ Guru SMA Negeri 1 Muaro Jambi 


\section{PENDAHULUAN}

Dewasa ini segala hal menjadi serba bebas dan tanpa arah. Aturan mengenai moralitas ada namun layaknya tidak ada. Istilah Arab menyebutnya "Wujuduhu $k a$ Adamihi", ada tapi seolah-olah tidak ada. Aturan moralitas tersebut bagi mayoritas dianggap sebagai pemanis dalam kehidupan. Bukan bermaksud mengatakan bahwa aturanitu tidak penting lagi, melainkan karakter mayoritas manusianya sendiri yang menganggap bahwa aturan itu tidak penting. Aturan hanya dianggap sebagai penghambat keinginan dan "nafsu" yang mengakibatkan terkekangnya jiwa sehingga tidak dapat menikmati dunia yang penuh gemerlap ini.

Hal itulah yang sekiranya menjadi potret nyata kehidupan generasi muda saat ini. Fenomena degradasi moral dikalangan generasi muda kini bukan menjadi hal yang langka untuk ditemui. Sebut saja penggunaan miras, narkoba, tindak kriminal dan seks bebasdikalangan remaja, serta masih banyak kasus lainnya. Yang lebih memprihatinkan lagi bahwa perilaku tersebut dilakukan oleh remaja usia belia bahkan pelajar yang notabene nya adalah sosok generasi muda terpelajar yang akan menerima tongkat estafet kepemimpinan bangsa selanjutnya.

Fakta sosial tersebut membuat tidak sedikit pelajarIndonesia kini berada dalam generasi dzurriyatan dhi'afan, yaitu generasi yang lemah iman, ekonomi, fisik mental, serta menjadi beban hidup orang lain. Hal ini tentunya menjadi sebuah ironi bagi keberlangsungan negara Indonesia ke depan. Kerena bagaimanapun pelajar sebagai generasi muda adalah harapan bagi setiap bangsa. Di pundak generasi muda masa depan dari suatu bangsa dipertaruhkan. Jika moral generasi mudanya hancur, maka niscaya akan hancurlah bangsa tersebut, begitupun sebaliknya.

Permasalahan ini menurut penulis merupakan hal yang serius, tidak ada jalan terbaik selain kita bersama-sama membentuk suatu situasi kesamaan persepsi dalam pemberdayaan generasi muda yang terencana, menyeluruh, terpadu, terarah, bertahap dan berkelanjutan untuk memacu tumbuh kembangnya generasi muda sebagaimana yang telah dicita-citakan oleh bangsa Indonesia. Bila dibiarkan lebih jauh bukan tidak mungkin bangsa Indonesia tidak akan pernah mencapai kejaayaannya.

Oleh karenanya, sebelum hal yang kita takutkan itu benar-benar terjadi, penulis ingin memberikan suatu kontribusi pemikiran yang dapat dijadikan alternatif solusi untuk mengatasi degradasi moral yang kini telah melanda siswa Indonesia dengan mengkonstruksi sebuah program pendidikan karakterterintegrasi yang penulis sebut dengan istilah Integrated Character Education Model.

Gagasan ini berangkat dari kajian penulis terhadap ketentuan sebagaimana yang termuat di dalam Undang-undang Nomor 20 Tahun 2003 Tentang Sistem Pendidikan Nasional. Di dalam ketentuan Pasal 1 ayat (1) undang-undang tersebut, disebutkan bahwa pendidikan diartikan sebagai usaha sadar dan terencana untuk mewujudkan suasana belajar dan proses pembelajaran agar peserta didik secara aktif 
mengembangkan potensi dirinya untuk memiliki kekuatan spiritual keagamaan, pengendalian diri, kepribadian, kecerdasan, akhlak mulia, serta keterampilan yang diperlukan dirinya, masyarakat, bangsa dan negara. Selanjutnya di dalam ketentuan Pasal 3 disebutkan pula bahwa pendidikan nasional berfungsi sebagai sarana mengembangkan kemampuan dan membentuk watak serta peradaban bangsa yang bermartabat dalam rangka mencerdaskan kehidupan bangsa, bertujuan untuk berkembangnya potensi peserta didik agar menjadi manusia yang beriman dan bertakwa kepada Tuhan Yang Maha Esa, berakhlak mulia, sehat, berilmu, cakap, kreatif, mandiri, dan menjadi warga negara yang demokratis serta bertanggung jawab.

Jika diperhatikan tujuan pendidikan sebagaimana yang termuat di dalam undang-undang tersebut, arah pembimbingan yang harus dilakukan adalah tidak hanya menjadikan peserta didik menjadi pribadi yang berkualitas dalam konteks intelektual melainkan perlu dilakukan pembimbingan yang juga diarahkan kepada pembentukan kapasitas jati diri. Berdasarkan pemahaman penulis terhadap undangundang tersebut, secara tersirat pemerintah membuka celah yang selebar-lebarnya kepada seluruh lembaga pendidikan untuk menerapkan Character Model Education sebagai salah satu program pendidikan di dalamnya, terlebih hal ini akan diformulasikan sebagai alternatif solusi dalam ikhtiar mengatasi degradasi moral yang kini telah melanda.

\section{Urgensi Integrated Character Education Model}

Di tengah arus globalisasi dan modernitas seperti sekarang ini, karakter dan moralitas bangsa menjadi satu dari sekian banyak persoalan utama yang dialami oleh negara-negara berkembang, termasuk Indonesia. Bagi negara-negara kapitalis, Indonesia merupakan pasar yang sangat potensial untuk memasarkan berbagai produk budayanya. Selain memiliki jumlah penduduk yang sangat besar, sebagian masyarakat Indonesia mempunyai sifat konsumtif dan latah sehingga sangat berpotensi dijadikan pangsa pasar yang menguntungkan bagi produk-produk dari bangsa lain.

Meskipun disadari bahwa tidak semua produk budaya asing menimbulkan dampak negatif, namun kehati-hatian tentu menjadi suatu keniscayaan yang perlu diutamakan. Kehati-hatian itu dapat direpresentasikan dengan upaya menyaring, memilah dan memilih apa yang baik dan apa yang tidak baik dari budaya tersebut. Upaya untuk menyaring, memilah, dan memilih bukan berarti menolak semua produk budaya asing yang masuk ke negeri ini. Apabila ada produk-produk budaya asing yang bernilai manfaat, seperti disiplin yang tinggi, kerja keras, dan lain-lain tidak menjadi masalah jika kita menerimanya. Sebaliknya, apabila produk-produk budaya asing itu dicurigai dapat menimbulkan efek yang kurang baik, dalam hal apapun, maka sebaiknya kita lebih bijak dalam menyikapinya atau menolak dengan cara yang elegan.

Lebih lanjut berkenaan dengan hal tersebut, satu dari sekian 
cara yang dapat dilakukan dalam upaya menyaring, memilah dan memilih hal sebagaimana dimaksud yakni melalui proses pendidikan. Proses pendidikan baik secara formal, informal, maupun nonformal pada prinsipnya menjadi tumpuan untuk melahirkan manusia baru Indonesia dengan karakter yang kuat. Adapun karakter kuat ini dicirikan oleh kapasitas moral seseorang, seperti kejujuran, kekhasan kualitas seseorang yang membedakan dirinya dari orang lain, serta ketegaran untuk menghadapi kesulitan, ketidakenakan, dan kegawatan.

Karakter bangsa yang kuat bisa diperoleh dari sistem pendidikan yang baik dan tidak hanya mementingkan faktor kecerdasan intelektual semata, melainkan juga pendidikan yang dilandasi dengan keimanan dan ketakwaan serta menghasilkan output yang tidak sekadar mampu bersaing di dunia kerja, namun juga mampu menghasilkan karya yang berguna bagi masyarakat, agama, bangsa, dan negara. Untuk mewujudkan hal itu, maka diperlukan pendidikan yang mencakup dua unsur utama, yaitu keunggulan akademik dan keunggulan nonakademik (termasuk keunggulan spiritual) yang kini akrab kita sebut dengan istilah pendidikan karakter.

Berbicara tentang pendidikan karakter, penulis teringat dengan ungkapan indah Phillips dalam The Great Learning: "If there is righteousness in the heart, there will be beauty in the character; if there is beauty in the character, there will be harmony in the home; if there is harmony in the home, there will be order in the nation; if there is order in the nation, there will be peace in the world". Dari ungkapan Philips, dapat diketahui bahwa arti penting dari pendidikan karakter adalah mengoptimalkan muatan-muatan karakter yang baik dan positif (baik sifat, sikap, dan perilaku budi luhur, akhlak mulia) yang menjadi pegangan kuat dan modal dasar pengembangan individu dan bangsa nantinya.

Lebih lanjut pendidikan karakter juga biasa diartikan sebagai pendidikan yang menanamkan dan mengembangkan karakter-karakter luhur kepada peserta didik, sehingga mereka memiliki karakter yang luhur, menerapkan dan mempraktikkan dalam kehidupannya baik di dalam keluarga, sebagai anggota masyarakat maupun warga negara. Pendidikan karakter sesungguhnya bukan sekedar mendidik benar dan salah, tetapi mencakup proses pembiasaan tentang perilaku yang baik sehingga peserta didik dapat memahami, merasakan dan mau berperilaku baik sehingga terbentuklah tabiat yang baik Menurut Thomas Lickona, sifat alami dari pendidikan karakter dimanifestasikan dalam tindakan nyata melalui tingkah laku yang baik, jujur, bertanggung jawab, menghormati orang lain dan karakter mulia lainnya. Lebih jauh Linckona menekankan tiga hal dalam mendidik karakter, yang dirumuskan dengan indah : knowing, loving, and acting the good.

Idealnya, pendidikan karakter yang paling baik itu adalah sejak di sekolah taman kanak-kanak (TK), pendidikan dasar hingga pendidikan menengah. Pendidikan karakter tersebut sebenarnya bisa menjadi kecakapan hidup mendasar (general life skills education), yang menjadi materi dasar utama di pendidikan 
dasar yaitu di TK, Sekolah Dasar dan Sekolah Menengah Pertama (SMP/MTS). Semakin ke jenjanglebih tinggi, porsinya semakin berkurang. Adapun ditingkatan Sekolah Menengah Atas (SMA), idealnya mental dan karakter anak itu telah terbentuk. Namun pada kenyataanya, akibat beberapa pengaruh seperti modernitas yang membawa budaya hedonis plus kapitalis, karakter sebagian besar siswa kita di tingkatan justru semakin tergerus.

Banyak orang (baca: pelajar) mengalami disorientasi identitas bukan hanya karena menghadapi krisis ekonomi, tetapi juga karena serbuan globalisasi nilai-nilai dan gaya hidup yang tidak selalu kompatibel dengan nilai-nilai dan norma-norma agama, sosial-budaya nasional dan lokal Indonesia. Sebagai contoh, gaya hidup hedonistik, materialistik dan permissif sebagaimana banyak ditayangkan dalam telenovela dan sinetron pada berbagai saluran TV Indonesia, hanya mempercepat disorientasi dan dislokasi keluarga dan rumahtangga. Akibatnya, tidak heran jika banyak anak-anak yang keluar dari keluarga dan rumahtangga hampir tidak memiliki watak dan karakter. Banyak di antara anak-anak yang alim dan bajik di rumah, tetapi nakal di sekolah, terlibat dalam tawuran, penggunaan obat-obat terlarang, pergaulan bebas, dan bentuk-bentuk tindakan kriminal lainnya, seperti penodongan, pencopetan, pencurian, dan sebagainya. Inilah anak-anak yang bukan hanya tidak memiliki kebajikan (righteousness) dan inner beauty dalam karakternya, tetapi malah mengalami kepribadian terbelah (splitpersonality).

Jika kita telaah lebih dalam mengenai pendidikan karakter sebagaimana yang dimaksud, sebenarnya sekolah baik Sekolah Dasar (SD), Sekolah Menengah Perama (SMP) dan Sekolah Menengah Atas (SMA) telah mencoba menginternalisasikanmodel pendidikan karakter yang dimanifestasikan dalam bentuk program pendidikan Kewaganegaraan dan pendidikan Agama dalam kurikulum pembelajarannya. Hanya saja model pedidikan semacam ini dirasa belum berhasil menciptakan pelajar dalam posisi on the track.

Belum berhasilnya implementasi kedua jenis pendidikan tersebut jangan dimaknai bahwa penulis menyebutnya sebagai sebuah kegagalan. Hanya saja belum berhasilnya tersebut menurut penulis disebabkan oleh dua hal pokok, yaitu: pertama, kurang terampilnya para tenaga pendidik (guru) menginternalisasikan pendidikan karakter dalam proses pembelajaran, karena pendidikan bukan sajamenyajikan mata pelajaran di dalam kurikulumnya, tetapi yang terpenting adalahmengimplementasikan perwujudan dari nilai-nilai pendidikan tersebut didalamtotalitas kehidupan peserta didik melalui perilaku terpuji; kedua bahwa pihak sekolah terlalu fokus mengejar targettarget akademik. Karena sekolah masih fokus pada aspek-aspek kognitif atau akademik, maka aspek soft skill atau nonakademik sebagai unsur utama pendidikan karakter justeru diabaikan. 
Hal ini kemudian membuat sekolah menjadi seolah tidak berdaya menghadapi kenyataan ini dan sekolah selalu menjadi kambing hitam dari merosotnya watak dan karakter bangsa. Padahal, sekolah sendiri menghadapi berbagai masalah berat menyangkut kurikulum yang overload, fasilitas yang tidak memadai, kesejahteraan guru dan tenaga kependidikan yang rendah. Menghadapi beragam masalah ini sekolah seolah kehilangan "relevansinya dengan pembentukan karakter". Sebagai konsekuensinya, sekolah kini lebih merupakan sekadar tempat bagi transfer of knowledge daripada character building, tempat pengajaran daripada pendidikan.

Berbagai hal yang telah penulis jelaskan diatas membuat penerapan Integrated Character Education Model sudah tidak dapat ditawar lagi sebagai alternatif solusi mengatasi degradasi moral pelajar di Indonesia. Model pendidikan karakter yang demikian mutlak diperlukan selain untuk membendung degradasi moral, juga berfungsi membentuk karakter pelajar yang kuat dan kokoh untuk menghadapi tantangan hidup di masa yang akan datang. Bagaimanapun juga karakter adalah kunci keberhasilan individu dalam menggapai sebuah tujuan yang mulia. Bahkan Theodore Roosevelt mengatakan: "To educate a person in mind and not in morals is to educate a menace to society" mendidik seseorang dalam aspek kecerdasan otak dan bukan aspek moral adalah ancaman mara-bahaya kepada masyarakat.

\section{Relevansi Integrated Character Education Model dengan Upaya Mengatasi Degradasi Moral Pelajar Indonesia}

Penataan kembali pendidikan karakter bangsa diperlukan tidak hanya karena infrastruktur kebangsasaan, kenegaraan, dan kemasyarakatan yang rawan krisis, melainkan juga karena dinamika perubahan tatanan dunia dengan semakin menguatnya arus globalisasi (arus orang, modal, barang, jasa, informasi, gaya hidup, nilai-nilai, budaya, lintas batas negara). Globalisasi, otonomi daerah, ketersediaan sumberdaya alam secara terbatas, degradasi lingkungan, degradasi moral dan intelektual serta potensi konflik antar kelompok (ras, suku, agama) secara nyata telah menciptakan berbagai krisis multi dimensi dalam konteks yang komplek. Berbagai krisis multi dimensi yang dihadapi bangsa Indonesia perlu dipandang sebagai tantangan untuk melakukan tatanan kembali terhadap pendidikan karakter bangsa menuju ke arah yang lebih baik, yaitu peradaban yang mampu membawa kehidupan bangsa ke arah yang semakin berkualitas dan bermakna.

Salah satu upaya nyata yang dapat penulis lakukan dalam rangka penataan kembali pendidikan karakter bangsa adalah dengan mengkonstruksi sebuah model baru pendidikan karakter yang penulis sebut dengan istilah pendidikan karakter terintegrasi atau Character Model Education. Model pendidikan karakter ini efektif dan aplikatif untuk diterapkan pada tiga jenjang pendidikan, yakni SMP, SMA dan Pendidikan Tinggi dengan melibatkan 
seluruh civitas akademika setiap jenjang pendidikan tersebut.

Lebih lanjut berkenaan dengan hal tersebut, Character Model Education yang penulis tawarkan secara konseptual akan diterapkan melalui tiga desain, pertama adalah desain berbasis kelas, yakni berbasis pada relasi tenaga pendidik sebagai pendidik dan peserta didik sebagai pembelajar. Dengan adanya relasi tersebut, diharapkan akan terciptanya iklim pendidikan yang ideal, yakni pendidikan yang merupakan upaya terencana dalam proses pembimbingan dan pembelajaran bagi individu agar berkembang dan tumbuh menjadi manusia yang mandiri, bertanggungjawab, kreatif, berilmu, sehat, dan berakhlak mulia; kedua, desain berbasis kultur sekolah, yang berusaha membangun kultur sekolah yang mampu membentuk karakter pelajar dengan bantuan pranata sosial sekolah agar nilai terbentuk dan terbatinkan dalam diri peserta didik; dan ketiga, desain berbasis komunitas sekolah.Hendaknya pihak sekolah tidak bekerja sendiri dalam melaksanakan pendidikan karakter. Akan tetapi, pihak sekolah hendaknya bekerjasama dengan komunitaskomunitas tertentu yang ada di lingkup sekolah seperti halnya Organisasi Siswa (OSIS) dilingkungan SMP dan SMA.

Kenapa sekolah tetap menjadi pilihan dalam upaya penataan kembali pendidikan karakter? Hal ini dikarenakan sekolah, pada hakikatnya bukanlah sekedar tempat "transfer of knowledge" belaka. Seperti dikemukakan Fraenkel (1977), sekolah tidaklah semata-mata tempat di mana guru menyampaikan pengetahuan melalui berbagai mata pelajaran. Sekolah juga adalah lembaga yang mengusahakan usaha dan proses pembelajaran yang berorientasi pada nilai (value-oriented enterprise). Lebih lanjut, sekolah adalah lembaga pendidikan yang berfungsi untuk meningkatkan kualitas moral, pengetahuan, keterampilan, dan sosial anak didik. Berbagai program dilaksanakan untuk mewujudkan fungsi agung tersebut. Ditambahkan pula oleh John Childs (dalam Fraenkel, 1977) yang menyatakan, bahwa organisasi sebuah sistem sekolah dalam dirinya sendiri merupakan sebuah usaha moral (moralenterprise), karena sekolah merupakan usaha sengaja masyarakat manusia untuk mengontrol pola perkembangannya.

Berikut adalah flow-chart program Integrated Character Education Model yang penulis tawarkan:

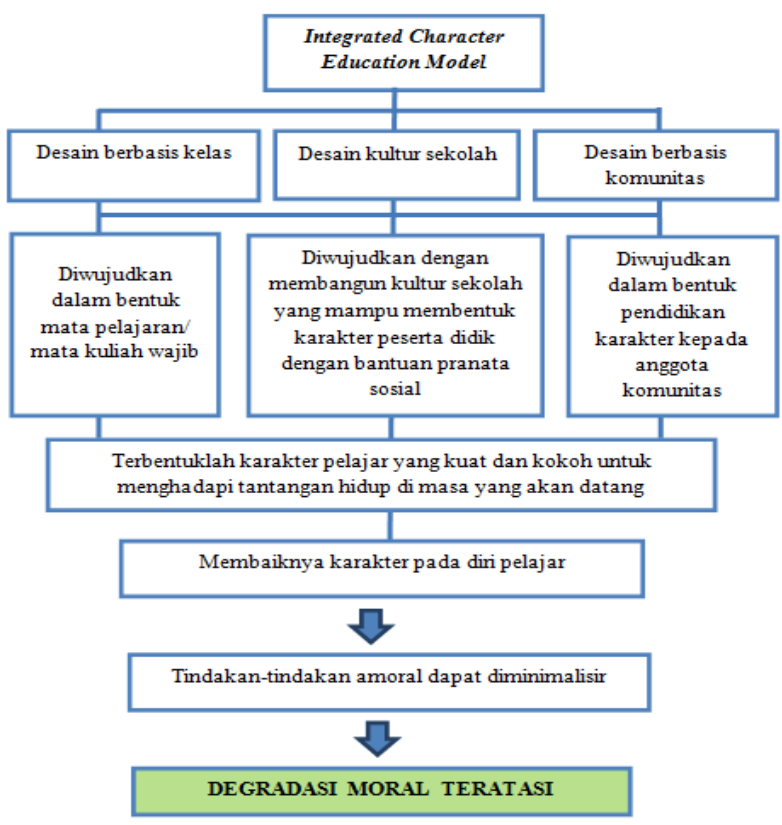
Gambar 1. Flow-chart program Integrated Character Education Model 
Dari flow-chart di atas, dapat dilihat bahwa Integrated Character Education Modelyang penulis gagas secara konseptual diterapkan melalui tiga desain. Hal ini percis sebagaimana penulis sebutkan sebelumnya. Pertama desain berbasis kelas. Integrated Character Education Model dengan desain yang demikian secara konseptual akan diwujudkan dalam bentuk mata pelajaran atau mata kuliah wajib di kelas 1 untuk SMP dan SMA serta semester 1 untuk Perguruan Tinggi. Kedua, desain berbasis kultur sekolah. Integrated Character Education Model dengan desain yang demikian secara konseptual akan diwujudkan dengan membangun kultur sekolah yang mampu membentuk peserta didik dengan bantuan pranata sosial. Desain yang demikian ini juga dikenal dengan pendekatan"modelling" atau "exemplary", yakni mensosialisasikan dan membiasakan lingkungan sekolah untuk menghidupkan dan menegakkan nilai-nilai akhlak dan moral yang benar melalui model atau teladan. Setiap guru dan tenaga kependidikan lain di lingkungan sekolah hendaklah mampu menjadi "model" yang hidup (living exemplary) bagi setiap peserta didik. Mereka juga harus terbuka dan siap untuk mendiskusikan dengan peserta didik tentang berbagai nilai-nilai yang baik tersebut. Ketiga desain berbasis komunitas. Integrated Character Education Model dengan desain yang demikian secara konseptual akan diwujudkan dalam bentuk pendidikan karakter kepada anggota komunitas yang dilakukan oleh komunitas bersangkutan dengan difasilitasi oleh sekolah. Keseluruhan desain tersebut bersifat komulatif. Artinya ketiganya harus dilaksanakan secara menyeluruh dan tidak mengkesampingkan satu diantaranya. Ketika keseluruhan desain tersebut dilakukan secara benar, penulis melihat ada sebuah harapan terhadap perbaikan karakter pada diri pelajar. Selanjutnya, ketika perbaikan karakter tersebut terus dibina dengan penerapan Integrated Character Education Modelyang dilakukan secara berkala, tindakan-tindakan amoral yang dilakukan pelajar niscaya akan dapat diminimalisir. Ketika tindakan amoral terminimalisir, lambat laun degradasi moral pelajar akan teratasi dan dalam kurun waktu tertentu akan terbentuklah karakter pelajar yang kuat dan kokoh untuk menghadapi tantangan hidup di masa yang akan datang.

Berdasarkan uraian di atas, maka terlihat jelas bahwa program Integrated Character Education Modelsangat relevan diterapkan sebagai alternatif solusidalam mengatasi degradasi moral pelajar di Indonesia. Bagaimana tidak,program Integrated Character Education Modelberimplikasi pada, pertama membaiknya karakter pelajar; dan kedua pelajar dapat memilah mana perbuatan yang seharusnya dilakukan dan mana perbuatan yang tidak seharusnya dilakukan. Ketika kedua hal tersebut telahterinternalisasikan dengan baik dalam setiap diri pelajar, maka degradasimoral yang kini terjadi niscaya tidak akan terulang dikemudian hari. Jauh lebihpenting dari itu adalah ketika degradasi moral telah dapat teratasi, bukan tidakmungkin dengan konsep yang demikian kita akan terbentuk karakter 
pelajarIndonesia yang kuat dan kokoh untuk menghadapi tantangan hidup di masa yang akan datang.

Agar implementasi Integrated Character Education Model di sekolah dapat berhasil, maka syarat utama yang harus dipenuhi diantaranya adalah: pertama, teladan pendidik,tenaga kependidikan dan pimpinan sekolahserta para pemangku kebijakan di instansi pendidikan, karena sebagaimana perumpamaan "guru kencing berdiri, murid kencing berlari"... maka pendidik harus memang benar-benar menjadi uswatun hasanah bagi peserta didiknya; kedua, pendidikan karakter atau yang dalam hal ini dinamakan sebagai Integrated Character Education Model tidak hanya harus dilakukan secara konsisten dan berkelanjutan melainkan harus ada kajian serta peningkatan serta dukungan penuh dari berbagai elemen sekolah agar program ini tidak hanya sebatas"formalitas" belaka; dan ketiga, penanaman nilai-nilai karakter yang utama. Karena semua tenaga pendidik adalah guru pendidikan, maka mereka memiliki kewajiban untuk memasukkan atau menginternalisasikan nilai-nilai pendidikan karakter dalam kegiatan pembelajarannya (intervensi).

Selain syarat di atas, perlu juga sekiranya memerhatikan apa yang disampaikan oleh Lickona agar Integrated Character Education Modeldi sekolah dapat berjalan secara efektif: pertama, kembangkan nilainilai etika inti dan nilai-nilai kinerja pendukungnya sebagai fondasi karakter yang baik; kedua, definisikan 'karakter' secara komprehensif yang mencakup pikiran, perasaan, dan perilaku; ketiga, gunakan pendekatan yang komprehensif, disengaja, dan proaktif dalam pengembangan karakter; keempat, ciptakan komunitas sekolah yang penuh perhatian; kelima, beri siswa kesempatan untuk melakukan tindakan moral; keenam, buat kurikulum akademik yang bermakna dan menantang yang menghormati semua peserta didik, mengembangkan karakter, dan membantu siswa untuk berhasil; ketujuh, usahakan mendorong motivasi diri siswa, kedelapan; libatkan staf sekolah sebagai komunitas pembelajaran dan moral yang berbagi tanggung jawab dalam pendidikan karakter dan upaya untuk mematuhi nilai-nilai inti yang sama yang membimbing pendidikan siswa; kesembilan, tumbuhkan kebersamaan dalam kepemimpinan moral dan dukungan jangka panjang bagi inisiatif pendidikan karakter; kesepluh, libatkan keluarga dan anggota masyarakat sebagai mitra dalam upaya pembangunan karakter; dan kesebelas evaluasi karakter sekolah, fungsi staf sekolah sebagai pendidik karakter, dan sejauh mana siswa memanifestasikan karakter yang baik.

\section{KESIMPULAN}

Berdasarkan uraian di atas, dapat disimpulkan bahwa untuk mengatasi degradasi moral pelajar Indonesia diperlukan upaya-upaya yang serius, salahsatu alternatif solusi yang penulis tawarkan adalah dengan mengkonstruksi sebuah program Integrated Character Education Model yang pelaksanaannya bisadilakukan melaui tiga desain secara komulatif yaitu desain berbasis kelas; desainberbasis kultur sekolah; 
serta desain berbasis komunitas. Melalui programIntegrated Character Education Model selain diharapkan mampu mengatasi degradasi moral pelajar tetapi juga mampu mewujudkan karakter pelajar yang kuat dan kokoh untuk menghadapi tantangan hidup di masa yang akandatang. Mewujudkan pelajar yang berkarakter haruslah dimaknai sebagai bagian dari cara untuk mewujudkan pelajar berdasarkan apa yang dicita-citakanoleh bangsa Indonesia sejak awal berdirinya.

\section{DAFTAR PUSTAKA}

\section{Buku}

Agus, Wibowo. 2012. Pendidikan Karakter Strategi Membangun Karakter Bangsa Bermartabat. Yogyakarta, Pustaka Pelajar.

Asmani, Jamal Ma'ruf. 2012. Kiat Mengatasi Kenakalan Remaja di Sekolah. Yogyakarta: Buku Biru.

Imam, Musbikin. 2013. Mengatasi Kenakalan Siswa Remaja: Solusi Mencegah Tawuran Pelajar, Siswa Bolos Sekolah Hingga Minum Minuman Keras dan Penyalahgunaan Narkoba. Riau: Zanafa Publishing.

Retno, Listyarti. 2012. Pendidikan Karakter dalam Metode Aktif,
Inovatif, \& Kreatif. Jakarta: Erlangga.

Komarudin, Hidayat dan Putut Widjanarko. 2008. Reiventing Indonesia: Menemukan Kembali Masa Depan Bangsa. Jakarta: PT Mizan Republika.

Jurnal dan Makalah

Didik, Suhardi. Peran SMP Berbasis Pesantren Sebagai Upaya Penanaman Pendidikan Karakter Kepada Generasi Bangsa. Jurnal Pendidikan Karakter: Vol II, No.3, Oktober 2012.

E. Dewi, Yuliana. Pentingnya Pendidikan Karakter Bangsa Guna Merevitalisasi Ketahanan Bangsa. Udayana Mengabdi: Vol 9, No. 2, 2010.

Hariadi. Integrasi Pendidikan Karakter Melalui Pembelajaran Tenis Mini. Cerdas Sifa: No.1, Mei-Agustus 2012.

Phillips, C. Thomas. Family as the School of Love. Makalah pada National Conference on Character Building. Jakarta: 25-26 November, 2000.

Website

http://opini.berita.upi.edu/page/2/ [diakses pada tanggal 2 Februari 2018]

http://josephsoninstitute.org/quotes/q uotations.php?q=Education [di akses pada tanggal 3 Februari 2018] 